\title{
Investment in public transport projects in cities: What do citizens think about it? \\ Francisco Javier Calvo Poyo
}

Assistant Professor, TRYSE Research Group. Department of Civil Engineering, University of Granada, ETSI Caminos, Canales y Puertos, c/ Severo Ochoa, s/n, 18071. Granada (Spain)

\section{Ramón Ferri García}

Researcher, TRYSE Research Group. Department of Civil Engineering, University of Granada, ETSI Caminos, Canales y Puertos, c/ Severo Ochoa, s/n, 18071. Granada (Spain)

\section{Javier Fernández Medina}

Researcher, TRYSE Research Group. Department of Civil Engineering, University of Granada, ETSI Caminos, Canales y Puertos, c/ Severo Ochoa, s/n, 18071. Granada (Spain)

\section{SUMMARY}

In recent years, important public transport infrastructures projects have been carried out in Andalusia (Spain), some of them having an important impact on life in the metropolitan areas. Nevertheless, no studies have been done to know the citizens' opinion concerning these projects. This article presents an analysis about the citizens' perception on this matter, based on a 2015 survey with a sample of 1,200 individuals living in the Andalusian capital cities. Citizens' perceptions about public transport infrastructures are analyzed, based on citizens' mobility preferences, on their opinion about transport infrastructures' social impact and about their adequation to the city they live in. Results indicate that people living in cities which already have underground have a larger preference for underground means of transport than those who live in cities that only have transit on surface. In addition, it is proved that light rail is the most unpopular transport mode among citizens.

\section{PUBLIC TRANSPORT IN ANDALUSIA}

All cities in the scope of study have urban and suburban bus service. Furthermore, Granada implemented a bus rapid transit (named High Capacity Line) in summer of 2014. Malaga and Seville have underground.

Moreover, Seville has a 2.2 kilometers long light rail line. In Granada a light rail line is being built since April 2007, suffering delays in its inauguration date, and Jaen line was inaugurated in 2011, but never started operating. Finally, there is another line (tram-train, in this case) being built in the metropolitan area of Cadiz. Suburban rail is present in three metropolitan areas: Seville, Malaga and Cadiz. The case of Cordoba should also be mentioned, with a little suburban rail line to the University (Cordoba-Rabanales). Nowadays, the implementation of a suburban rail network is being considered by the city council (Contreras, 2015). To end, every province capital city in Andalusia has a bicycle lane 
network. Seville was designed the best biking network in Spain according to its comfort and safety by the Customers and Users Organization (S.A., 2013).

\section{METHODOLOGY}

To analyze citizens' perception about public transport infrastructures, a telephone survey (both transit users and not users) with the CATI system on provinces capital cities in Andalusia was performed. Sample size was 1,200, meaning the maximum sampling error was $1.48 \%$, slightly higher than the sampling error with Neyman allocation (1.44\%) due to reweighting based not only on population size but also on the different transport modes that each city presents and their state at the sampling moment. To analyze survey data, $95 \%$ confidence intervals were used, under normality assumption for means or proportions of the variables. Given that most of the times the sample size for each subset was greater than 30 , normality could be assumed according to the Central Limit Theorem. Thanks to the confidence intervals, statistically significant conclusions (mean differences) could be extracted from the studio.

\section{RESULTS}

\subsection{On surface or underground transport}

The obtained results show that only $35.91 \%( \pm 1.39)$ of the inhabitants of provinces capital cities prefer underground public transport. However, as Figure 1 shows, this percentage gets statistically greater in the cities having underground (Seville and Malaga). 


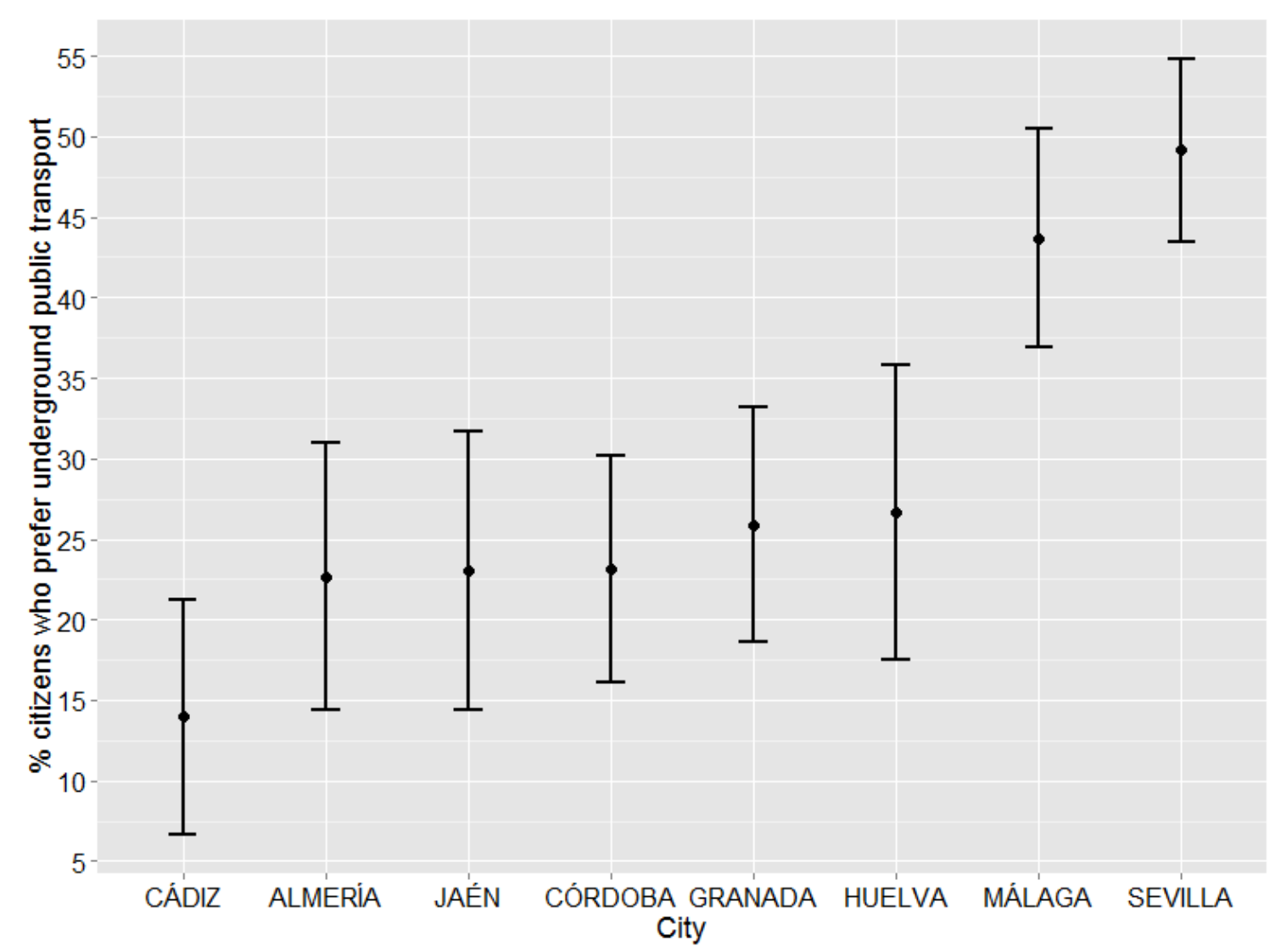

Fig. 1 - Percentage of citizens preferring underground means of transport

These differences could be explained by the fact that the citizens of Malaga and Seville are used to underground means of transport and thus know firsthand its advantages, while in other towns like Granada they only know about the negative issues (long construction period, etc.), or simply they do not find the underground option adequate for their city. On the other hand, it has to be mentioned that underground public transport systems are maybe more suitable for Malaga and Seville, as they have more population, are more spatially extended and have more road congestion problems.

\subsection{Investment}

$60.54 \%$ of the population thinks investment on public transport infrastructures in their city should have been greater, in contrast with $7.21 \%$ who think it should have been smaller. On the other hand, $21.56 \%$ of the citizens think that the investment amount was satisfactory, while $10.31 \%$ did not answer the question. These percentages vary between cities (Figure 2). 


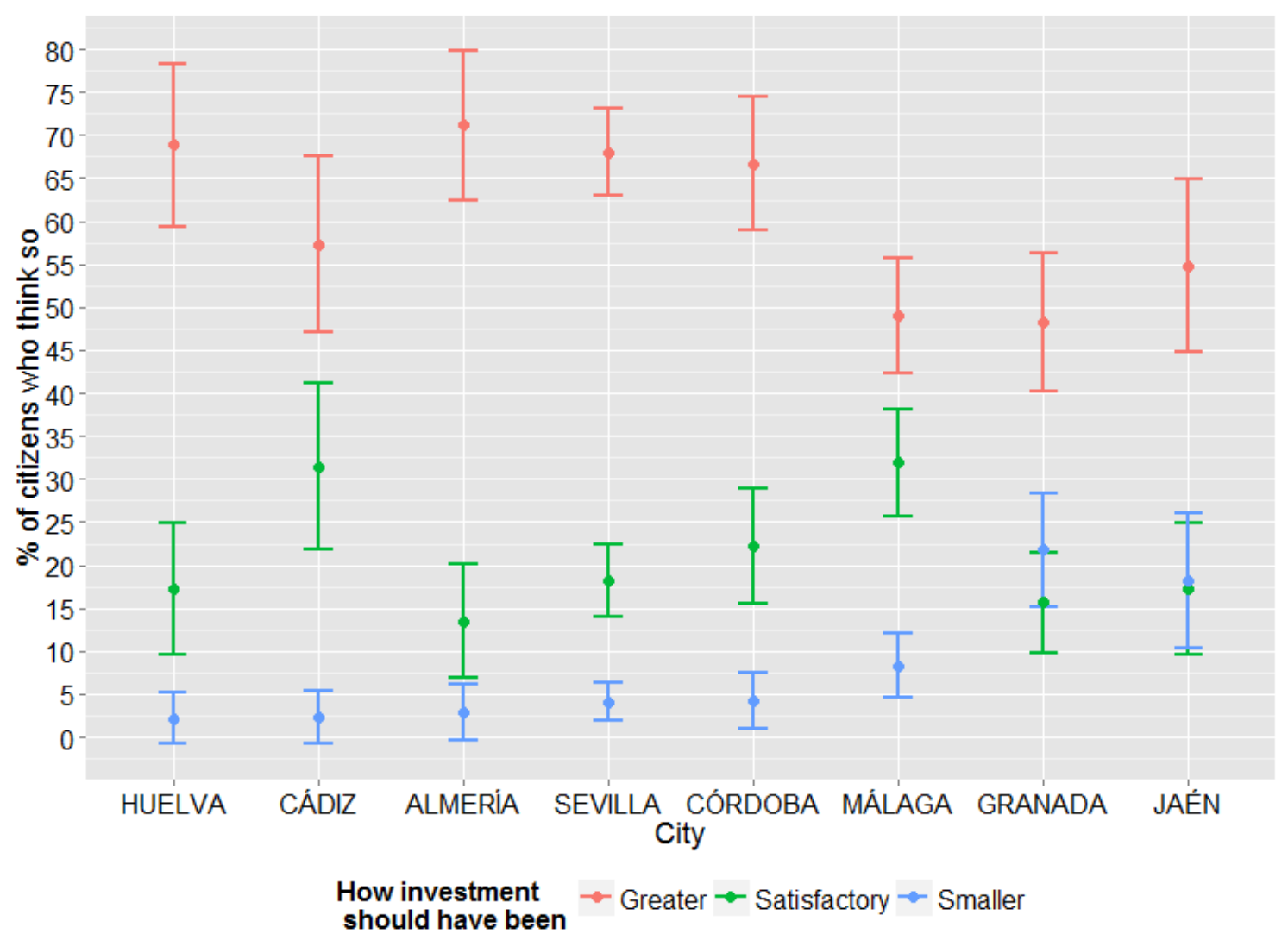

Fig. 2 - Opinion on investment volume in public transport infrastructures

The most remarkable conclusion here is the percentage of people who think investment should have been smaller in Granada and Jaen. In contrast with the rest of the cities, in these two cities people considering that investment should have been smaller are not minority. Furthermore, the proportion of habitants in these cities thinking that investment should have been greater is among the smallest in Andalusia. This could be explained by the light rail projects in these cities. In the case of Jaen, the project cost $120 \mathrm{M} €$ (Donaire, 2013), but it has not operated further than its inauguration day. On the other hand, the case of Granada could be explained by its light rail long construction period (still not operating), and the ex tra charges it has suffered: from $230 \mathrm{M} €$ in 2005 (Ordóñez, 2005) to $559 \mathrm{M} €$ in 2014 (Martín, 2014).

\subsection{Impact of public transport infrastructure projects}

Citizens showed a quite high degree of agreement with the statement saying that public transport infrastructure projects have a positive impact on life (except for the light rail). The positive impact of light rail, according to the citizens' opinion, was statistically lower than the positive impact of the rest, as shows Figure 3. 


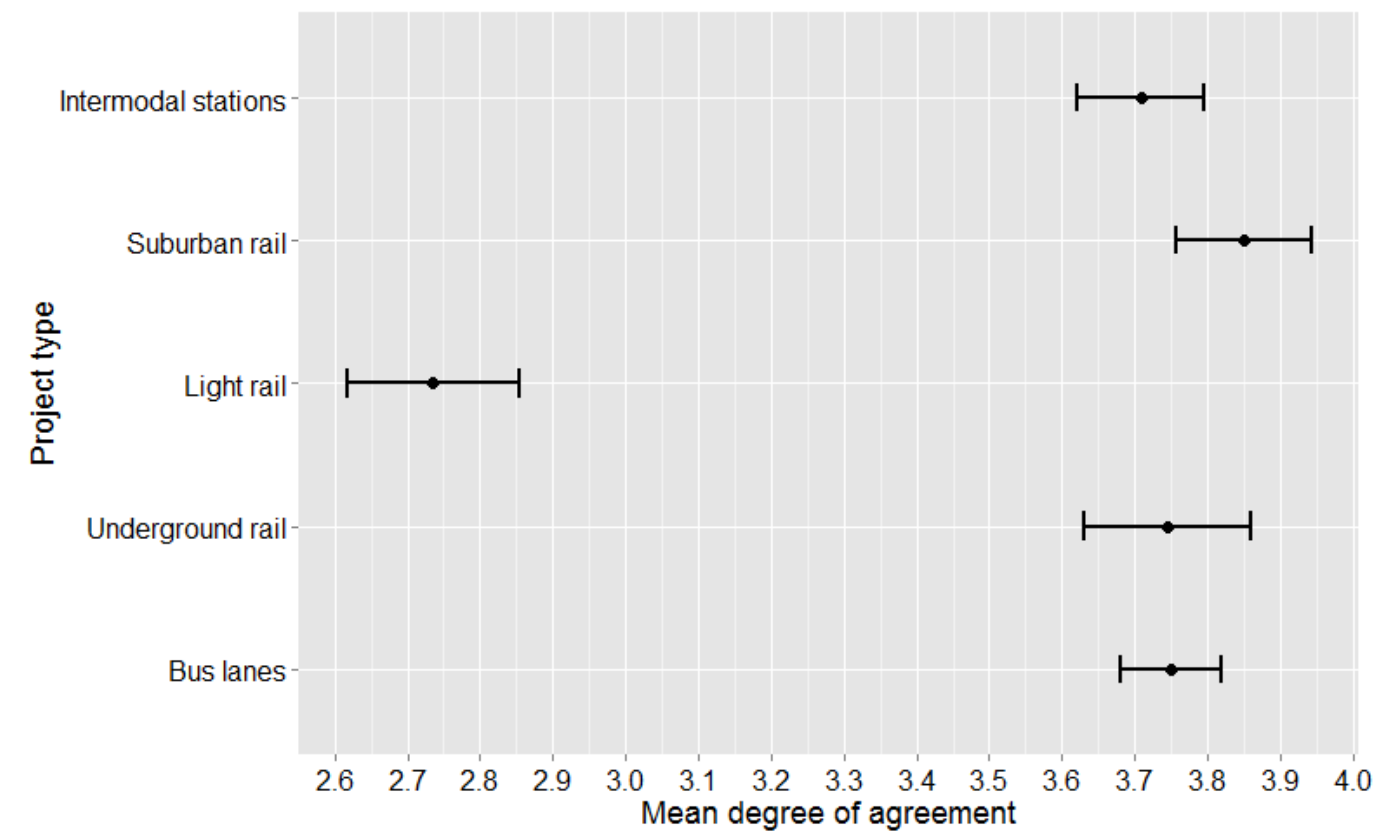

Fig. 3 - Confidence intervals of mean degree of agreement about positive impact of transit projects

In addition, the degree of agreement with the statement for each project was uniform among cities (no statistical differences on mean reported) except for bus lanes and light rail, as it can be seen in Figure 4.
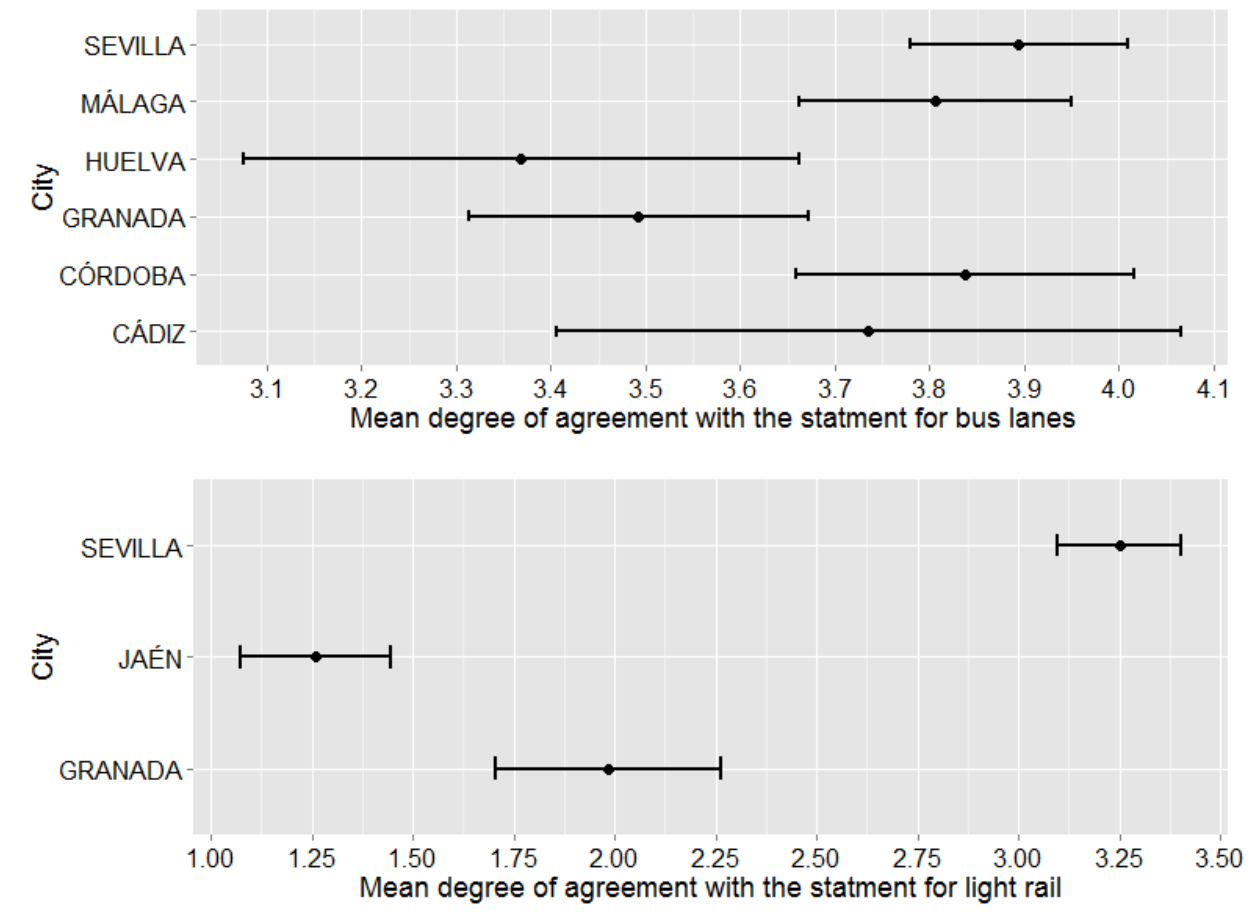

Fig. 4 - Confidence intervals of mean degree of agreement about positive impact of transit projects 
The perceived positive impact of bus lanes is statistically greater in Seville, Malaga and Cordoba (in the last two cities at a confidence level slightly lower than 95\%) than in Huelva and Granada. In the case of Granada, this could be explained by the general unpopularity of the brand new High Capacity bus line among population. The very low reported positive impact perceived rates of light rail for Jaen and Granada in comparison with Seville could be explained for the reasons developed in 4.2 .

\subsection{Adequation of transport modes to the city}

According to citizens, urban bus is the most adequate transport mode for the cities of study (Figure 6). Motorbike is considered more adequate than the car, probably because of the restrictions for car use in the centers of Andalusian cities. Suburban rail is considered much better than underground and light rail. Light rail is considered the least adequate transport mode.

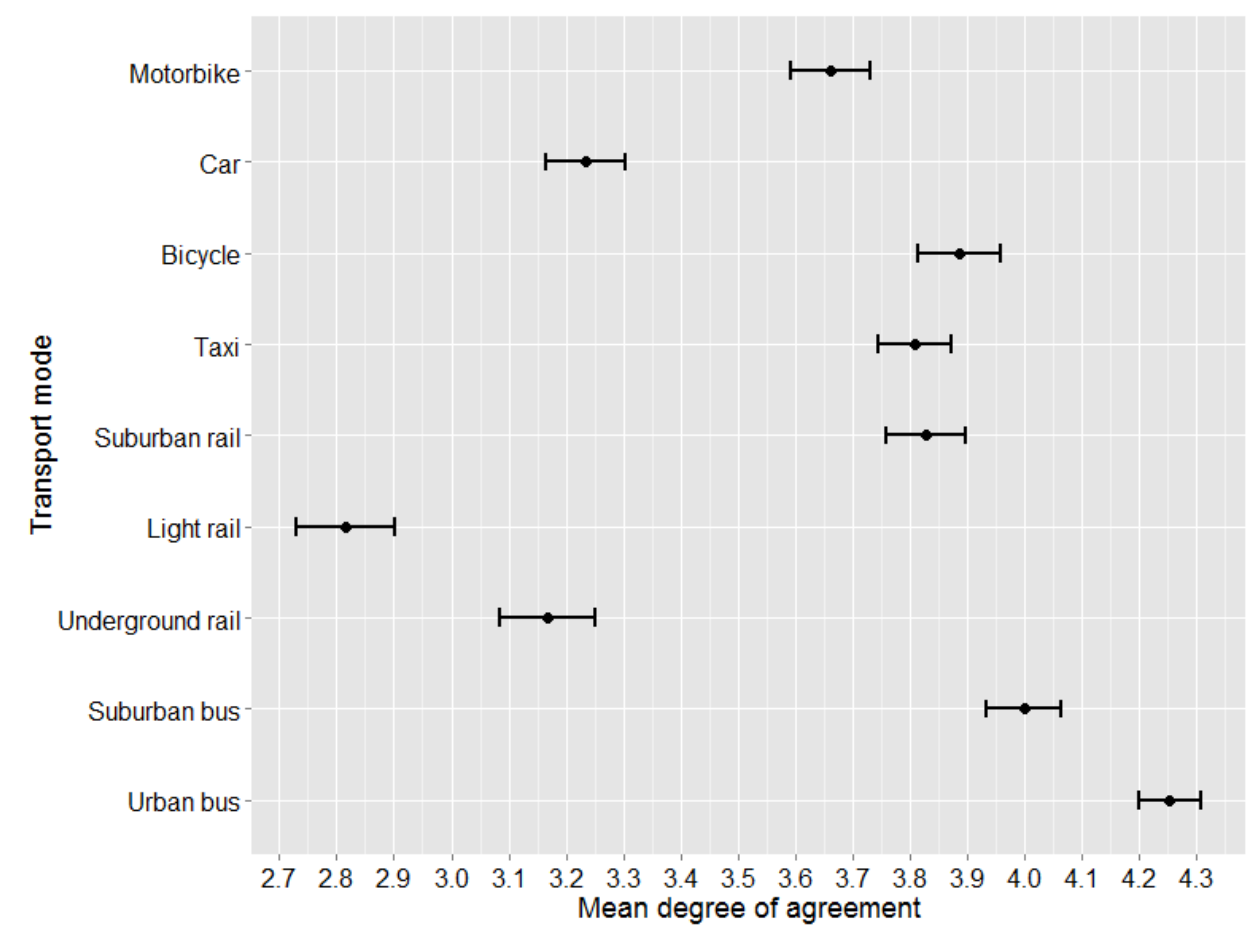

Fig. 5 - Confidence intervals of mean degree of agreement about means of transport suitability to the city

According to Figure 7, there are several differences in the opinion about the adequation of each transport mode between cities. For example, the inhabitants of the cities that already have a suburban rail are the ones who statistically consider this transport mode more adequate for their city (except for the case of Seville regarding Cordoba and Huelva). Again, cities with underground (Seville and Malaga) present much better scores than cities that do not have this means of transport. On the other hand, these two cities are the biggest in the study area, what indicates that maybe the big cities inhabitants are the ones who most approve high capacity transport modes. Bicycle suitability is significantly worse in Jaen than 
the rest of the capital cities, probably because of the failure of its bike loan service (Liébana, 2013).
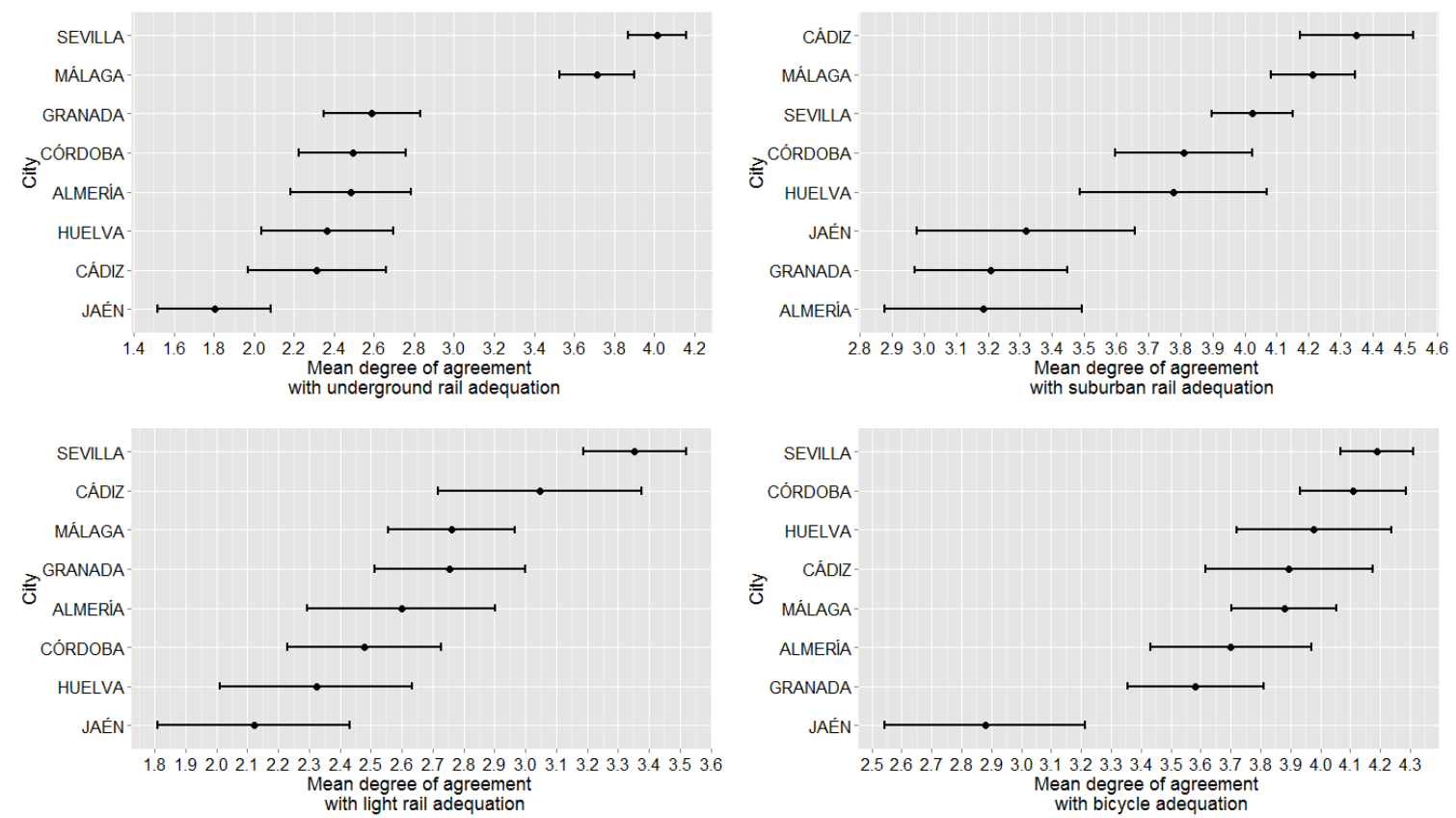

Fig. 6 - Confidence intervals of mean degree of agreement about adequation of transport modes by city

\section{CONCLUSIONS}

Firstly, results indicate that underground has a better reputation in cities with this means of transport. This could be related to the fact that inhabitants from those cities (which, on the other hand, are the biggest in the study area) value the advantages of underground, while inhabitants from the rest of the cities do not consider this means of transport adequate for their city, or they only know about its disadvantages (lack of accessibility, long construction period, etc.), and therefore they prefer public transport on surface.

Most of the people think that investment in public transport infrastructures should have been greater. The proportion of people thinking that investment should have been smaller is bigger in Granada and in Jaen (statistically speaking in Granada and almost statistically speaking in Jaen) than in the rest of the cities. This may be due to the problems with their light rail projects (delay on the opening date in the first case and canceled service in the second case). Moreover, citizens from Granada and Jaen expect much smaller positive impact from light rail than citizens from Seville. Urban and suburban buses are considered the most adequate transport modes for the Andalusian capital city provinces, probably because of their preference for surface transport and for the medium size of the cities. Light rail has been signaled as the least adequate transport mode, being only considered as partly adequate in Seville and Cadiz. Suburban rail is viewed as more adequate in cities that already have this means of transport. 


\section{ACKNOLEDGEMENTS}

The authors would like to thank the ERDF of European Union for financial support via project "Herramienta para la evaluación previa de infraestructuras de transporte público" of the "Proyectos de I+D+i 2014-2015". We also thank to Public Works Agency and Regional Ministry of Public Works and Housing of the Regional Government of Andalusia.

\section{REFERENCES}

CONTRERAS, I. (2015). Una comisión sin políticos estudiará la propuesta del Metrotren. ABC Córdoba. http://sevilla.abc.es/andalucia/cordoba/20150905/sevi-metrotren-politicoscordoba-201509041943.html

LIÉBANA, J. M. (2013). Los nuevos carriles bici propuestos llegan hasta el corazón de la capital. Ideal Jaén. http://www.ideal.es/jaen/v/20130924/jaen/nuevos-carriles-bicipropuestos-20130924.html

MARTÍN, J. (2014). El metropolitano de Granada sería económicamente sostenible a partir de los 70 céntimos por billete. GranadaDigital. http://www.granadadigital.es/elmetropolitano-de-granada-seria-economicamente-sostenible-a-partir-de-los-70-centimospor-billete/

ORDOÑEZ, J. L. (2005). Tranvías en concesión. Vía Libre, 483, pp. 59-72.

S. A., A. (2013). Sevilla tiene el carril bici más seguro y mejor conectado del país. Diario de

Sevilla.

http://www.diariodesevilla.es/article/sevilla/1599834/sevilla/es/la/ciudad/con/mejores/vias/ ciclistas.html

DONAIRE, G. (2013). El tranvía de Jaén, 120 millones tirados a una vía muerta. El País. http://ccaa.elpais.com/ccaa/2013/05/24/andalucia/1369396376_116395.html 